\title{
Olmesartan modulates proliferating cell nuclear antigen expression and improves dextran sulfate - induced ulcerative colitis in rats
}

\author{
Amany N. Ibrahim ${ }^{1}$, Noha I. Hussien ${ }^{2}$, Hanan Tawfeek Emam ${ }^{1 *}$
}

${ }^{1}$ Department of Clinical Pharmacology, Faculty of Medicine, Benha University, Egypt
${ }^{2}$ Department of Medical Physiology, Faculty of Medicine, Benha University, Egypt

Received: 12 January 2021

Revised: 02 February 2021

Accepted: 06 February 2021

\section{*Correspondence:}

Dr. Hanan Tawfeek Emam,

Email: hanantawfeek@yahoo.com

Copyright: (c) the author(s), publisher and licensee Medip Academy. This is an open-access article distributed under the terms of the Creative Commons Attribution Non-Commercial License, which permits unrestricted non-commercial use, distribution, and reproduction in any medium, provided the original work is properly cited.

\begin{abstract}
Background: Ulcerative colitis (UC) is a chronic inflammatory bowel disease characterized by sudden attacks of remissions and exacerbations with increased incidence of cancer colon. The present study aims to determine the possible ameliorative mechanisms of Olmesartan in UC induced experimentally in rat.

Methods: Adult albino rats were randomly grouped into control, UC model non treated group: Rats received dextran sodium (DSS) orally for 21 days with intra-colic administration of acetic acid (AA) for 3 consecutive days for induction of UC model, Olmesartan $(1,5,10 \mathrm{mg} / \mathrm{kg} /$ orally) and UC + Olmesartan in different doses (1 mg, $5 \mathrm{mg}$ and $10 \mathrm{mg} / \mathrm{kg} / \mathrm{day}$ orally).

Results: DSS orally and AA intra-rectal produced sever colitis manifested by significant weight loss, watery and bloody diarrhea. Significant increase in serum and colonic tissue levels of tumor necrosis factor alpha and interleukine-1 $\beta$. Proapoptotic Bax protein, myeloperoxidase (MPO) and expression of PCNA significantly increased in colonic tissue. Lipid peroxidation (MDA) significantly elevated while reduced glutathione (GSH) was depleted in UC non-treated group compared with normal control group. Treatment with Olmesartan $(5 \mathrm{mg}, 10 \mathrm{mg} / \mathrm{kg} / \mathrm{day}$, orally) ameliorated mucosal ulceration and improved inflammatory signs as confirmed by immunohistochemical and histopathological examination. Also, Olmesartan significantly attenuates overexpression of PCNA in colonic mucosa.

Conclusions: Our results point out that Olmesartan had ameliorative effects on UC by its anti-inflammatory, antioxidant and anti-apoptotic effects and attenuates PCNA expression which is the main cause of dysplasia and colorectal cancer. Olmesartan may be a promising therapeutic drug for treating UC and protection of colorectal carcinoma.
\end{abstract}

Keywords: UC, Olmesartan, Dextran sulfate TNF- $\alpha$, MPO, PCNA

\section{INTRODUCTION}

Inflammatory bowel disease (IBD) is a chronic inflammatory bowel disease of large intestine characterized by attacks of sudden remissions and exacerbations. IBD has a high prevalence in industrialized nations. ${ }^{1}$

Ulcerative colitis (UC) is one of IBD that affect large intestine. The exact cause of UC remains unknown, possible cause is an immune system malfunction, family history manipulation of intestinal flora and environmental causes may have a role. ${ }^{2}$

In addition to free radicals, the inflammatory process is accompanied by inflammatory cells infiltration to mucosa of the gut and upregulated release of pro-inflammatory mediators like, tumor necrosis factor alpha (TNF- $\alpha)$, cytokines, reactive oxygen species (ROS) in colonic tissue. ${ }^{3}$ 
The level of TNF- $\alpha$ is increased in both UC model in rats and in patients with UC. ${ }^{4}$ This cytokine is a key regulatory cytokine secreted by antigen presenting cell (macrophages). It exaggerates the inflammatory cascades by stimulating more macrophages, increased release of interleukins, activation of T-lymphocyte, increase infiltration of neutrophils to the site of inflammation, increase lipid peroxidation and inhibit coagulation. ${ }^{5}$

Dextran sulfate sodium salt (DSS) induced colitis is well known method for induction of UC. This model produced clinical picture similar to human UC disease. It produced mucosal ulceration, neutrophile infiltration, increased release of free oxygen species and cytokines release in colon mucosa. ${ }^{6}$

The therapeutic strategies used in UC treatment depends on severity, type and site of illness. It consists of corticosteroids, sulfasalazine and immunosuppressive drugs like and biological treatment like infliximab. ${ }^{3}$ The main goal of treatment is stop progression of the disease, inhibit inflammation and prevent complications. Unfortunately, these drugs had many side effects and patients do not cured completely and relapse may occur after short time. So, the discovery of new drugs to inhibit inflammation and prevent complications mainly dysplasia and cancer has been necessary.

Recent studies showed that renin angiotensin system have a central role in pathogenesis of UC and tissue injury. ${ }^{7}$ Angiotensin 1 (AT1) is found abundant in all layers of the colon. ${ }^{8}$ Ang II receptor blockers (ARBs), has been as found to inhibit the tumor necrosis factor (TNF)- $\alpha$ produced stimulation of nuclear factor $(\mathrm{NF})-\kappa \mathrm{B}$ in vascular endothelial cells. ${ }^{9}$

Olmesartan medroxomil is orally active, non-peptide angiotensin receptor antagonist. ${ }^{10}$ Olmesartan binds selectively with high affinity to the AT1 receptor. ${ }^{11} \mathrm{New}$ studies reported that, olmesartan have antioxidant and immunomodulatory properties in different experimental models. $^{12}$

To date, the ant- proliferative effect of Olmesartan has not been studied before in the models of UC. Therefore, our aim was to determine the possible anti-proliferative, antiinflammatory, anti-apoptotic and antioxidant effects of Olmesartan in UC model induced experimentally in rats.

\section{METHODS}

\section{Drugs and chemicals}

Acetic acid: (El-Naser Pharmaceutical Chemicals Co., Egypt). Other drugs, chemicals and reagents (SigmaAldich co., Cairo. Egypt).

\section{Animals}

Adult male albino Sprague-Dawley rats (Helwan Farm), with an average weight of 180-200grams were used. They have acclimatized for one week and were caged (5/cage) in fully ventilated room at room temperature in the Pharmacology Department, Benha Faculty of Medicine. Rats were allowed free access to water and balanced diet. The study period extended from July-2019 to September2019. All ethical protocols for animal treatment were followed and supervised by the animal facilities. This experiment was approved by institutional animal care committee of Benha faculty of Medicine, Benha University.

\section{Method of induction of ulcerative colitis}

Rats not allowed to eat eight hours before induction of colitis but allowed to access to water containing dextran sulfate $6 \mathrm{mg} / \mathrm{kg}$ for 21 days with intracolonic instillation of $1 \mathrm{ml}$ of $2 \%$ AA dissolved in saline for 3 consecutive days using soft fine catheter. Rats were anaesthetized by large dose of ether during the instillation of AA. After catheter lubrication with gel inserted into colon $8 \mathrm{~cm}$ proximal to anal opening. Rats were maintained in a supine Trendelenburg position for 30 seconds to prevent leakage of the intracolonic instillation. All rats were kept under thiopental anesthesia $(50 \mathrm{mg} / \mathrm{kg}$; administered by intraperitoneal (i.p) injection) during administration of acetic acid. This is a modification of the method of Matuszyk and his team who used only rectal acetic acid and Randhawa and his team, who used dextran sodium sulfate alone. ${ }^{6,13}$ The purpose of this modification is to ensure the induction of acute severe case of ulcerative colitis with minimal animal mortality and cost.

\section{Experimental design}

Ninety male adult albino rats were randomly divided into the following groups, each one comprised 10 rats.

Group 1: (a) (normal control group): they receive no drugs. (b) Rats were given drug vehicle (normal saline) both oral and rectal in comparable volumes and in the same schedule as treated groups.

Group II: (a) Rats were administrated olmesartan at $1 \mathrm{mg} / \mathrm{kg} /$ day, (b) Rats were administrated olmesartan at 5 $\mathrm{mg} / \mathrm{kg} /$ day orally, and (c) Rats were administrated olmesartan at $10 \mathrm{mg} / \mathrm{kg} / \mathrm{day}$ orally, for the same period of the experiment.

Group III: positive control group (UC non-treated).

Group IV: UC + (Olmesartan $1 \mathrm{mg} / \mathrm{kg} /$ day/orally) ${ }^{14}$ starting three days before induction of UC and for 21 th day of experiment.

Group V: UC + (Olmesartan $5 \mathrm{mg} / \mathrm{kg} /$ day/orally) starting three days before induction of UC and for 21 th day of the experiment. 
Group VI: UC + (Olmesartan 10mg/kg/day/orally) starting three days before induction of UC and for 21th day of the experiment.

\section{Parameters measured}

Measurements of body weight loss, stool consistency and presence of blood in stool

Comparing the percentage of body weight loss at the end of the experiment with that calculated at the beginning of the experiment before UC induction. Assessing stool consistency and presence of blood in stool according to Wirtz and his team. ${ }^{2}$ Briefly, parameter was scored as follows: weight loss of (0, none, $1-5 \% ; 1,5-10 \% ; 2,10-$ $20 \%$; 3 , and $>20 \%$ was scored as 4$)$. For stool consistency (0, normal, 1and 2; soft stools and 3; watery diarrhea). Bleeding was scored ( 0 , no blood, 1,2 minimal bleeding, 3 , 4; gross bleeding).

\section{Biochemical parameters}

\section{Assessment of TNF- $\alpha ; I L-1 B$ and IL-10}

All animals were fasted overnight and blood samples were taken at the 22th day morning from rat tail of all groups. All blood samples were incubated in $37^{\circ} \mathrm{C}$ then centrifuged at 15000 R.P.M for 15 minutes. The supernatant serum was harvested and kept at $4^{\circ} \mathrm{C}$ prior to measurement: IL1B was measured by ELISA kit obtained from Biolegend (San Diego, CA, USA). TNF- $\alpha$, interleukin-10 were measured by ELISA using commercial kits obtained from eBioscience (Vienna, Austria). Then rats were sacrificed after i.p injection of thiopental $50 \mathrm{mg} / \mathrm{kg}$ by decapitation then the colonic tissue was rapidly removed and cleaned in an isotonic saline. The specimens from large intestine were fixed in $10 \%$ formalin followed by dehydration, clearing and embedding in paraffin. Transverse sections were cut 4-6 $\mu \mathrm{m}$ thickness to be subjected to the following techniques:

\section{Colonic histopathological changes}

Hematoxylin and eosin staining: For detection of general structures by histopathological examination of the colon according to Weaker and Richardson. ${ }^{15}$ Combined Alcain blue - PAS technique: for demonstration of acidic, neutral or mixed mucin in goblet cell in colonic tissue. ${ }^{8}$

\section{Immunohistochemical study}

Immunohistochemical detection of TNF- $\alpha$ consistence with the inflammatory condition of the cell. Immunohistochemical observation of Proliferating cell nuclear antigen (PCNA): PCNA is a nuclear protein whose appearance consistence with the G1/S phase of the cell cycle. Colon tissue fixed in $10 \%$ formalin then paraffin blocks stained with immunohistochemistry stain avidin biotin peroxidase technique for proliferating cell nuclear antigen (PCNA): PCNA monoclonal antibody (clone pc
10) was purchased from Lab Vision USA by Medico Trade Company, Giza, Egypt. ${ }^{12}$

Measurements of colonic tissue TNF- $\alpha$ and myeloperoxidase

The detection of expression of colonic tissue TNF-a was estimated using a commercially sandwich Elisa kits for rats according to manufacturer's instructions. Unit of measurement of TNF- $\alpha$ was $\mathrm{pg} / \mathrm{mg}$ protein.

\section{Measurements of myeloperoxidase}

Myeloperoxidase (MPO) activity was used as indictor of neutrophil aggregation. Tissue MPO activity was assessed using a commercial assay kit (Hycult Biotech Inc., Burlington, CA) expressed as U/g protein.

\section{Estimation of colonic tissue malondialdehyde and reduced} glutathione

The extent of damage of lipid by diseases liberating oxygen free radicals can be measured from the concentration of substances which react with thiobarbituric acid (thiobarbituric acid reacting substances - TBARS), one of which is malondialdehyde (MDA) according to manufacturer's instructions. ${ }^{16}$ Amount of $\mathrm{GSH}$ in colon tissues was determined by colorimetric method described by Noffsinger and his colleges. ${ }^{17}$ Values were expressed as $\mathrm{nmol} / \mathrm{g}$ tissue.

\section{Estimation of apoptotic and anti-apoptotic markers}

Bax and Bcl-2 levels were measured by using ELISA assay kits according to the manufacturer's instructions.

\section{Statistical analysis}

All the data were collected and presented in mean and standard deviation using Statistical Package for Social Science software computer program version 22 (SPSS, Inc., Chicago, IL, USA). One-way analysis of variance (ANOVA) with Post Hoc turkey tests were used for comparing quantitative parametric differences among the groups. Significant difference was considered at $\mathrm{p}<0.05$. Data represented as mean $\pm \mathrm{SD}$.

\section{RESULTS}

Effects of Olmesartan on weight loss, stool consistency and presence of blood in stool in ulcerative colitis experimentally induced in rats

DSS in a dose of $6 \mathrm{mg} / \mathrm{kg}$ in drinking water for 21 days plus with intra-colonic installation of $1 \mathrm{ml}$ of $2 \%$ acetic acid every 3 days to rats produced significant loss of body weight, increase rectal bleeding and watery diarrhea in both UC-non treated group and olmesartan $(1 \mathrm{mg} / \mathrm{kg} / \mathrm{day}$, orally) treated group compared with normal control group. While, administration of olmesartan $(5$ and $10 \mathrm{mg} / \mathrm{kg} /$ day, 
orally) in UC groups showed significant improvement of all disease scoring index in comparison with ulcerative colitis untreated group (Figure 1).

Results showed that there is no significant difference between group Ia and Ib. Also, there were no significant difference between group IIa, IIb, IIc and normal control group.
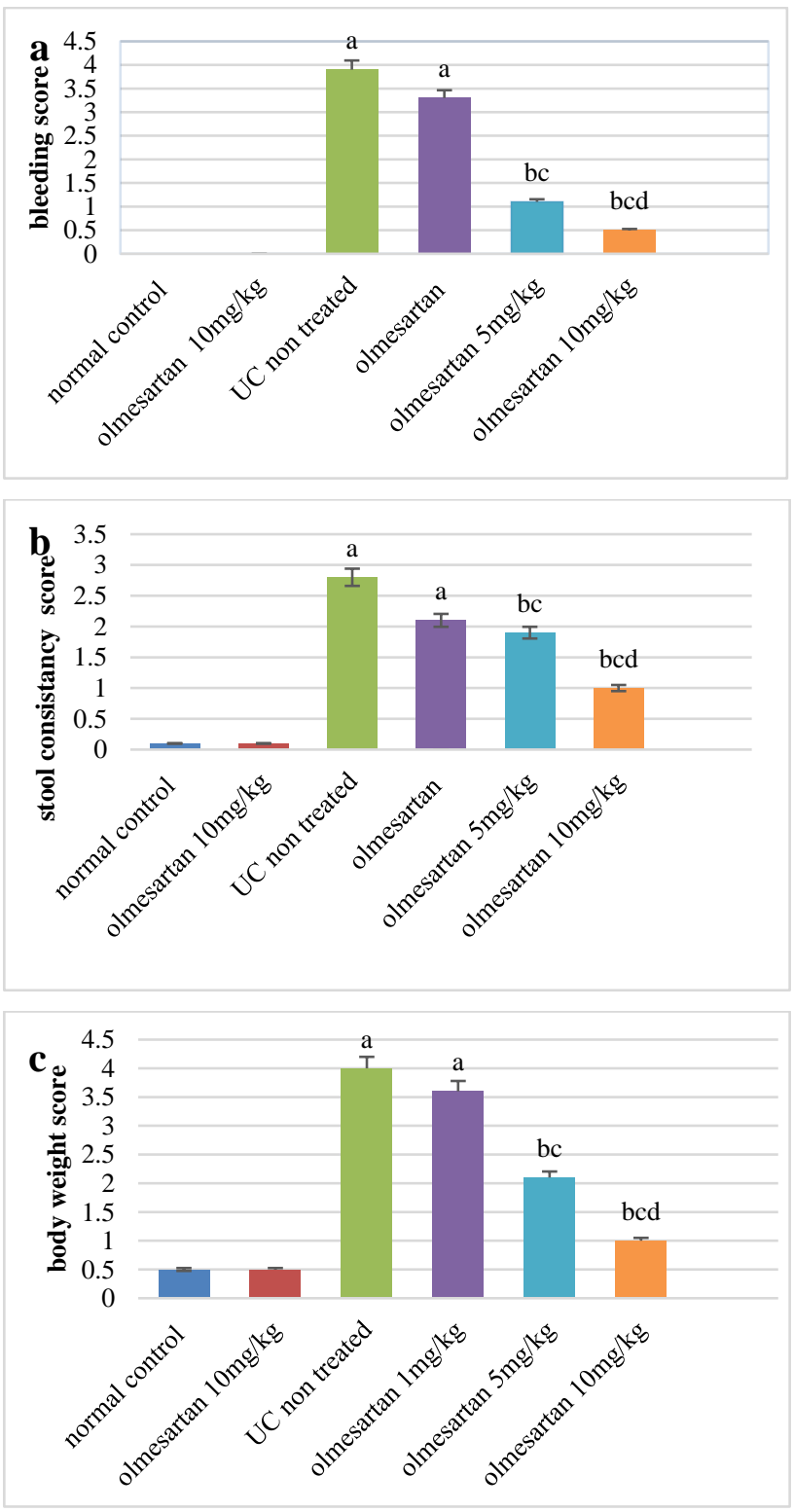

Figure 1 (a-c): Effects of Olmesartan (1, 5 and 10 $\mathrm{mg} / \mathrm{kg} /$ orally) on body wt. loss, stool consistency and bleeding in differences studied groups.

$\mathrm{N}$ : B: (a) significant difference between UC non-treated group with normal control group, (b) significant difference between olmesartan treated groups and UC non treated group, (c) significant difference between olmesartan $5 \mathrm{mg} / \mathrm{kg}$ treated group and olmesartan $1 \mathrm{mg} / \mathrm{kg}$ treated group, and (d) significant difference between olmesartan $10 \mathrm{mg} / \mathrm{kg} /$ day treated group and olmesartan $5 \mathrm{mg} / \mathrm{kg}$ treated group.

\section{Effects of Olmesartan on serum cytokines and pro- inflammatory mediators in differences studied groups}

In UC non treated group and olmesartan $(1 \mathrm{mg} / \mathrm{kg} / \mathrm{day}$, orally) treated group there were significant increase in IL$1 \beta$ and TNF- $\alpha$. While, anti-inflammatory IL-10 was decreased compared with normal control group (Figure 2). Administration of olmesartan $(5 \mathrm{mg} / \mathrm{kg}$ and $10 \mathrm{mg} / \mathrm{kg} /$ day, orally) produced significant decrease in levels of interleukine- $1 \beta$ and tumor necrosis factor- $\alpha$. While, the anti-inflammatory IL-10 was elevated in comparison with UC-non treated group (Figure 2).
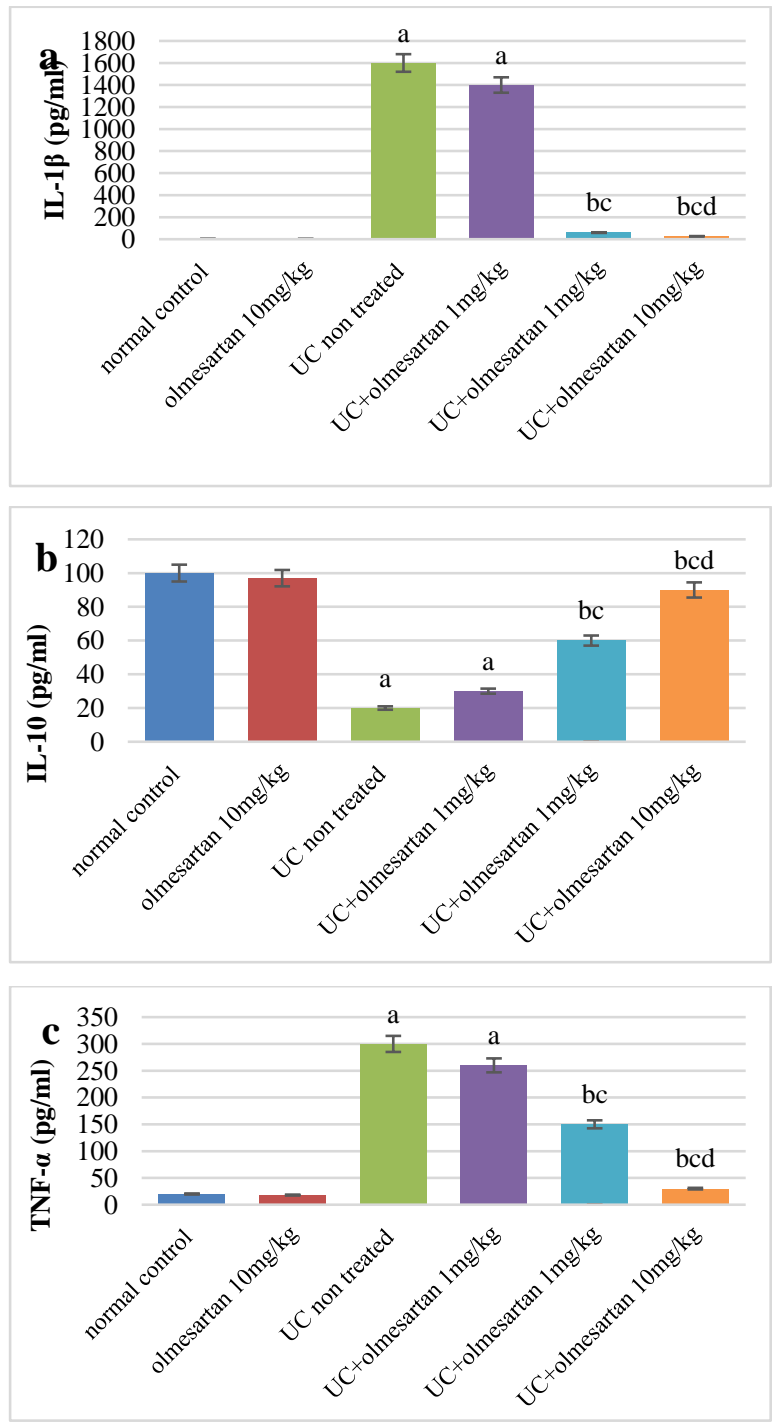

Figure 2 (a-c): Effects of olmesartan $(1,5$ and 10 $\mathrm{mg} / \mathrm{kg} /$ orally) on interleukine-1 $\beta$, tumor necrosis factor $-\alpha$ and interleukine-10 in different studied groups.

$\mathrm{N}$ : B: (a) significant difference between UC non-treated group with normal control group, (b) significant difference between olmesartan treated groups and UC non treated group, (c) significant difference between olmesartan $5 \mathrm{mg} / \mathrm{kg} /$ day treated group and olmesartan $1 \mathrm{mg} / \mathrm{kg} /$ day treated group, d: significant difference between olmesartan $10 \mathrm{mg} / \mathrm{kg} /$ day treated group and olmesartan $5 \mathrm{mg} / \mathrm{kg} /$ day treated group. 


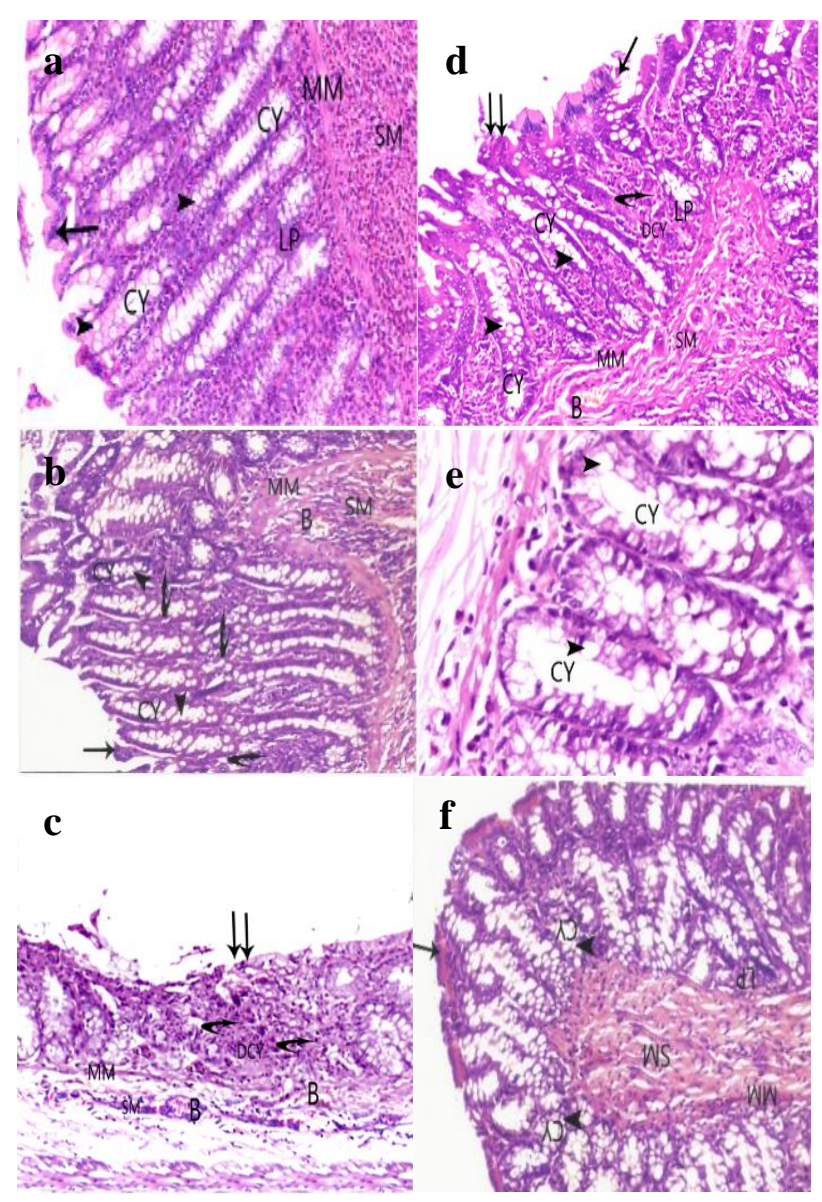

Figure 3: (a) Cut section $n$ of large intestine of normal control group with normal mucosa show simple columnar absorptive cells (arrow) with goblet cells. (b) cut section of a large intestine from olmesartan (10 $\mathrm{mg} / \mathrm{kg} /$ day, orally) showing normal mucosa with simple columaner cells, with many goblet cells, with no inflammatory cells infilteration or congested blood vessls. (c) cut section of a large intestine from (UC + olmesartan $1 \mathrm{mg} / \mathrm{kg} /$ day) treated group showing normal crypts (CY) lined with many goblet cells (arrows head), also there are damaged crypts (DCY) wit neutrophilic infiltration (curved arrow). (d) cut section of a large intestine of a rat (UC + olmesartan $5 \mathrm{mg} / \mathrm{kg}$ treated group) showing significant reduction of mucosal ulceration and necrosis with goblet cells (head arrows). Lamina propria (LP) shows normal crypts with many goblet cells with no neutrophilic infiltration. (e) cut of a large intestine of a rat from UC non-treated group showing ulcerative enteritis and extensive necrosis (double arrows). Lamina propria show damaged crypts (DCY), heavy neutrophilic infiltration (curved arrows) which extended to musculosa layer. (f) cut section of large intestine of a rat from (UC + olmesartan $10 \mathrm{mg} / \mathrm{kg}$ treated group) showing marked reduction of ulceration and neutrophilic infiltration lesions with many goblet cells in between crypts (curved arrow). The submucosa shows congested blood vessels $(\mathrm{B})$.
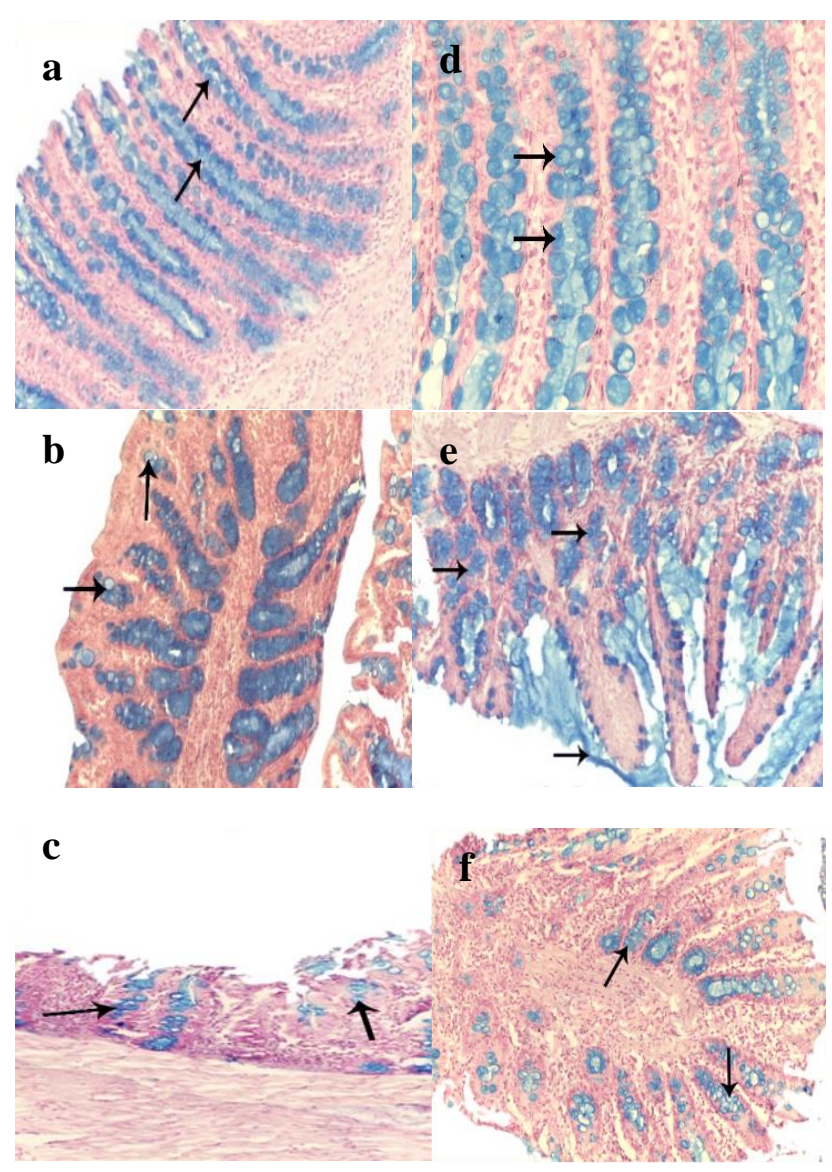

Figure 4: (a) Cut section of rat large intestine from normal control group with many alcian blue +ve goblet cells (arrows). (b) cut section of rat large intestine in olmesartan $10 \mathrm{mg} / \mathrm{kg} / \mathrm{day}$, orally group with many alcain blue + ve goblet cells. (c) cut section of rat large intestine of UC-non treated group with numerous alcian blue +ve goblet cells. (d) cut section of rat large intestine of $\mathrm{UC}+$ Olmesartan $1 \mathrm{mg} / \mathrm{kg} / \mathrm{day}$ treated group showing moderate alcian blue +ve goblet cells. (e) cut section of rat large intestine of $\mathrm{UC}+$ Olmesartan $5 \mathrm{mg} / \mathrm{kg} /$ day treated group showing decreased in intensity of alcian blue +ve goblet cells. (f) a cut section of rat large intestine of $\mathrm{UC}+$ Olmesartan $10 \mathrm{mg} / \mathrm{kg} / \mathrm{kg}$ treated group showing marked decrease in intensity of alcian blue +ve goblet cells.

\section{Effects of olmesartan on histopathological changes in rat colon}

\section{Hematoxylin and eosin-stained sections of the colon}

In normal control group revealed common shape of the large intestinal tissue (Figure 3a). While, in ulcerative colitis non- treated group and olmesartan $(1 \mathrm{mg} / \mathrm{kg} / \mathrm{day}$, orally) treated group, transverse section of a distal colon showed ulceration, necrosis and crypt abscess. The lamina propria and submucosa showed heavy inflammatory cell infiltration. There was attenuated muscularis mucosa and submucosal congested blood vessels in both groups (Fig. $3 \mathrm{~b}, 3 \mathrm{c})$. On the other hand, in $\mathrm{UC}+\operatorname{olmesartan}(5$ 
$\mathrm{mg} / \mathrm{kg} /$ day and $10 \mathrm{mg} / \mathrm{kg} /$ day) the transverse section of a distal colon showed a remarkable healed mucosa with marked decrease of inflammatory cells in lamina propria and sub mucosa. Lamina propria show exhibit tight arranged crypts, with many goblet cells and absence of congested blood vessels (Figure 3d and 3e).

Effects of olmesartan on combined Alcian blue-PAS reaction

For demonstration of acidic, neutral or mixed mucin in goblet cells of the colon, combined Alcian blue -PAS reaction was used. Histological examination of Alcian blue stained colon sections of group I reveals numerous Alcian blue positive goblet cells (Figure 4a). While, histological examination of Alcian blue stained colon sections of UC non-treated group and olmesartan $(1 \mathrm{mg} / \mathrm{kg} / \mathrm{day})$ treated group reveals few Alcian blue positive goblet cells (Figure $4 \mathrm{c}$ and $4 \mathrm{~d})$. On the other hand, in olmesartan $(5 \mathrm{mg} / \mathrm{kg} /$ day and $10 \mathrm{mg} / \mathrm{kg} /$ day) reveals numerous Alcian blue positive goblet cells and excessive amount of mucus covering surface (Figure 4e and 4f).

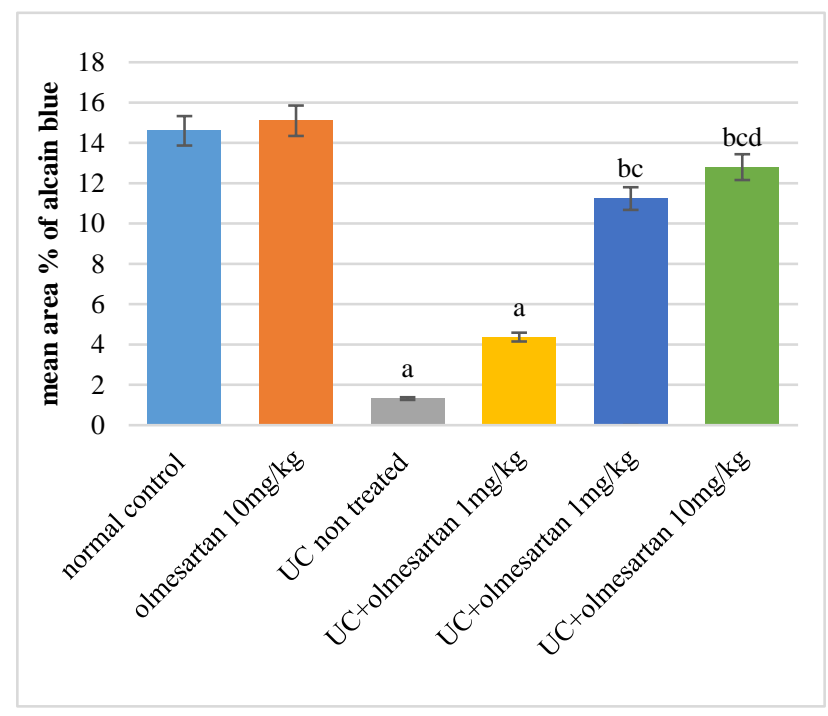

Figure 5: Histogram showing the mean area \% of Alcain blue-positive goblet cells \pm SD in different studied groups.

$\mathrm{N}$ : B: (a) significant difference between UC non-treated group with normal control group, (b) significant difference between olmesartan treated groups and UC non treated group, (c) significant difference between olmesartan $5 \mathrm{mg} / \mathrm{kg}$ treated group and olmesartan $1 \mathrm{mg} / \mathrm{kg}$ treated group and (d) significant difference between olmesratn $10 \mathrm{mg} / \mathrm{kg} /$ day treated group and olmesartan $5 \mathrm{mg} / \mathrm{kg}$ treated group.

\section{Effects on immunohistochemical changes}

Effects of olmesartan on immunohistochemical detection of $T N F-\alpha$

Histological examination of TNF- $\alpha$ in colon sections of group I (normal control group) reveals minimal declaration of TNF- $\alpha$ (Figure 6a) while, histological examination of TNF- $\alpha$ in colon sections of ulcerative colitis non - treated group reveals dense declaration of tumor necrosis factor- $\alpha$ in compare with normal control group (Figure 6c). Histological examination of tumor necrosis factor- $\alpha$ in colon sections of $\mathrm{UC}+$ olmesartan (1 $\mathrm{mg} / \mathrm{kg} /$ day) treated reveals moderate declaration of TNF- $\alpha$ in compare with UC control group (Figure 6d). Moreover, histological examination of tumor necrosis factor- $\alpha$ in colon sections of UC + olmesartan ( 5 and $10 \mathrm{mg} / \mathrm{kg} /$ day $)$ groups reveal low declaration of $\mathrm{TNF}-\alpha$ in compare with UC control group (Figure 6e and 6f).

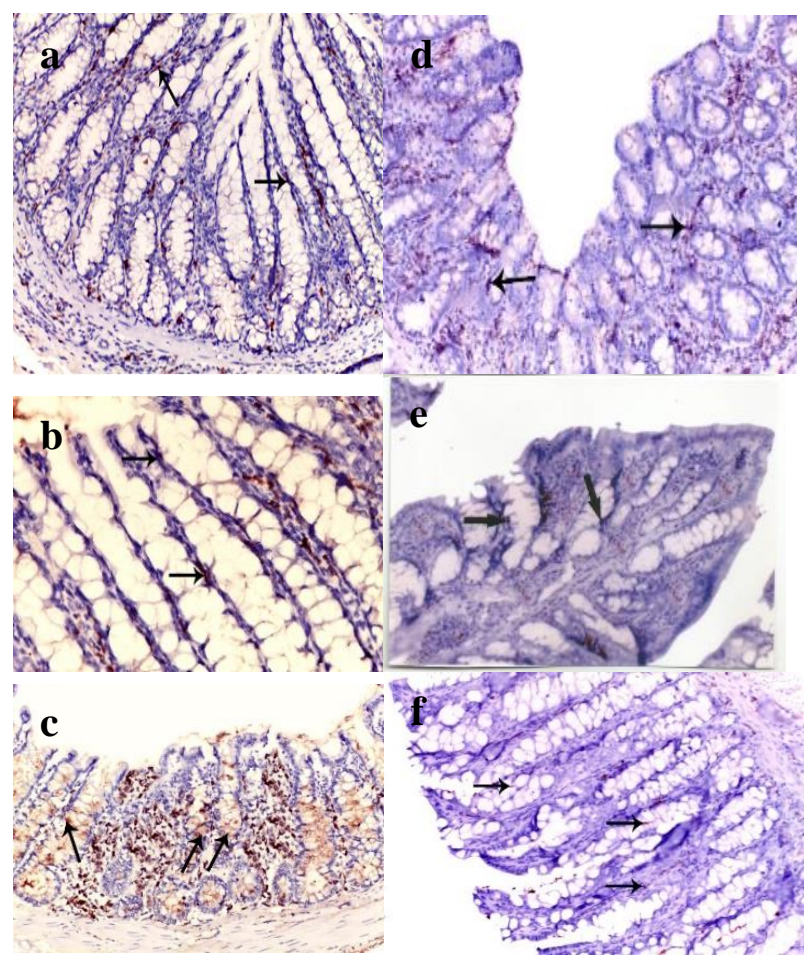

Figure 6: (a) Cut section of rat large intestine from normal control with minimal declaration of TNF- $\alpha$ (arrows). (b) A cut section of rat large intestine from of Olmesartan $10 \mathrm{mg} / \mathrm{kg} /$ day treated rats showing minimal TNF- $\alpha$ declaration (arrow). (c) A cut section of large intestine of rat from ulcerative colitis nontreated group with dense declaration of TNF- $\alpha$ (arrows). (d) A cut section of large intestine of rat

from UC + Olmesartan (1 mg/kg/day) showing moderate declaration of TNF- $\alpha$ (arrows). (e) A cut section of ra large intestine from $\mathrm{UC}+$ Olmesartan $(5$ $\mathrm{mg} / \mathrm{kg} /$ day) treated group showing minimal declaration of TNF- $\alpha$ (arrows). (f) A cut section of rat large intestine from UC + Olmesartan (10 mg/kg/day) treated group showing minimal declaration of TNF-a (arrows).

Effects of olmesartan on immunohistochemical detection of PCNA

Histological examination of PCNA in colon sections of normal control reveals normal immune-positive nuclei in the mucosal cells (Figure 8a). While, histological examination of PCNA in colon sections of group UC non- 
treated group reveals high immune-positive nuclei in the mucosal cells (Figure 8c). Histological examination of PCNA in colon sections of UC+ olmesartan $1 \mathrm{mg} / \mathrm{kg}$ treated group reveals moderate increase number of immune-positive nuclei of the cells lining the mucosal surface compared to UC non treated (Figure 8d). Also, histological examination of PCNA in colon sections of (UC + olmesartan $5 \mathrm{mg} / \mathrm{kg} /$ day and $10 \mathrm{mg} / \mathrm{kg} /$ day treated groups) reveals few immune-positive nuclei in the cells lining colon mucosa (Figure 8e and f).

Effects of olmesartan on colonic tissue expression of TNF$\alpha$ and myeloperoxidase

TNF- $\alpha$ and myeloperoxidase were at a low level in the control group. Induction of ulcerative colitis produced significant increase in the declaration of both TNF- $\alpha$ and myeloperoxidase in all examined colonic tissue on day 22. While, treatment with olmesartan in a dose of (5 $\mathrm{mg} / \mathrm{kg} /$ day and $10 \mathrm{mg} / \mathrm{kg} /$ day) suppressed significantly the elevation of TNF- $\alpha$ and myeloperoxidase in all examined tissues compared with UC-non treated group (Table 1). While, treatment with olmesartan $(1 \mathrm{mg} / \mathrm{kg} / \mathrm{day}$, orally) produced non-significant decrease in the levels of tumor necrosis factor- $\alpha$ and myeloperoxidase in comparison with UC non treated group (Table 1).

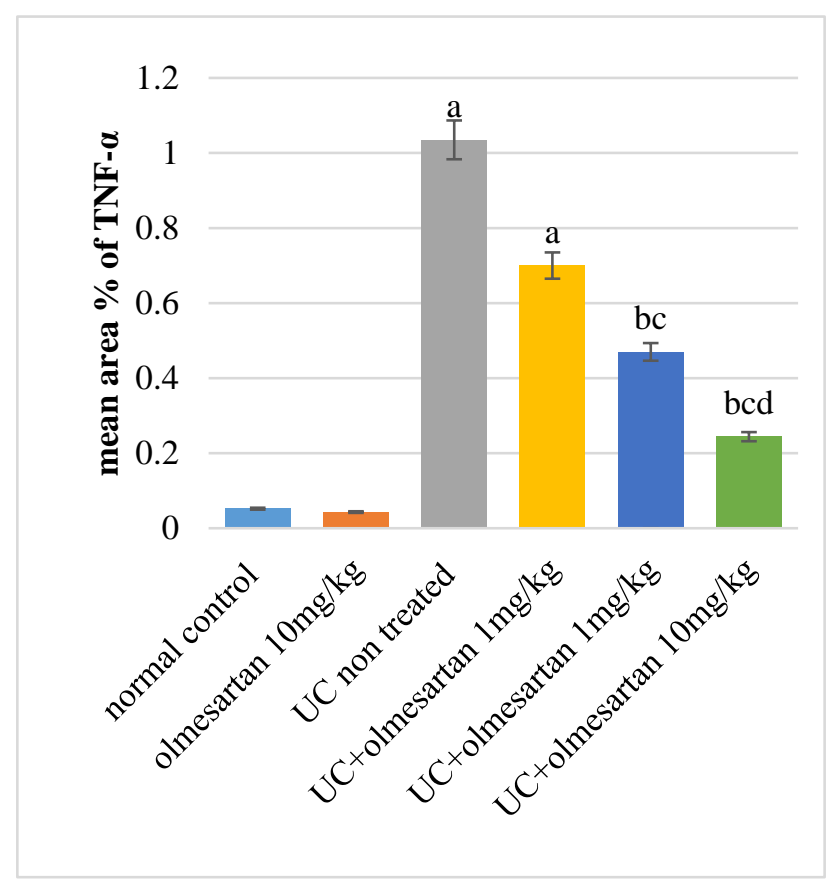

Figure 7: Histogram showing the mean area $\%$ of

TNF- $\alpha \pm$ SD in different studied groups.

$\mathrm{N}$ : B: (a) significant difference between UC non-treated group with normal control group, (b) significant difference between olmesartan treated groups and UC non treated group, (c) significant difference between UC + olmesartan $5 \mathrm{mg} / \mathrm{kg} /$ day treated group and olmesartan $1 \mathrm{mg} / \mathrm{kg}$ treated group and (d) significant difference between UC + olmesratn $10 \mathrm{mg} / \mathrm{kg} /$ day treated group and UC + olmesartan $5 \mathrm{mg} / \mathrm{kg} /$ day treated group.

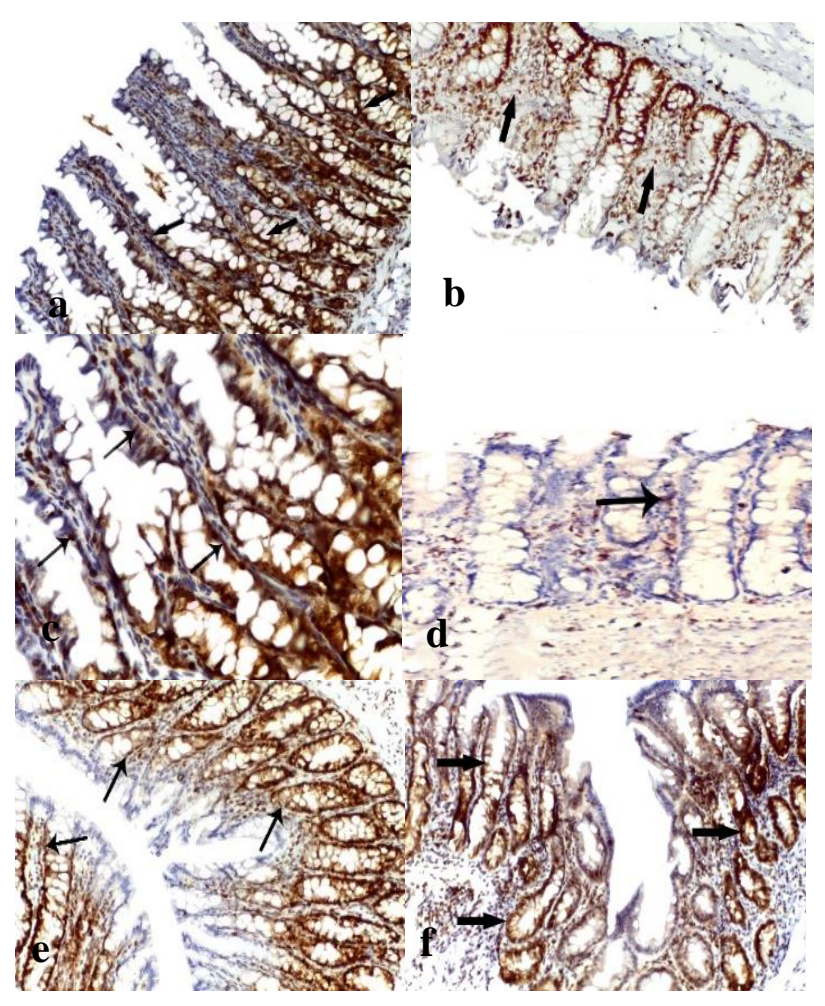

Figure 8: (a) A cut section of rat large intestine from normal control group with intense immune reaction with normal immune-positive nuclei in the mucosal cells (arrows). (b) A cut section of large intestine of rat from Olmesartan $10 \mathrm{mg} / \mathrm{kg} /$ day group with intense immune reaction with normal immune-positive nuclei in the mucosal cells (arrows). (c) A cut section of large intestine of rat from UC non- treated group showing overexpression of immune-positive nuclei in the mucosal cells (arrows). (d) A cut section of large intestine of rat from $\mathrm{UC}+$ Olmesartan $1 \mathrm{mg} / \mathrm{kg}$ treated group showing immune reaction with normal immune-positive nuclei in the cells lining the mucosal surface than group II (arrows). (e) A cut section of large intestine of rat from $\mathrm{UC}+$ Olmesartan $5 \mathrm{mg} / \mathrm{kg} /$ day treated group showing moderate immune reaction with moderate immune-positive nuclei in the cells lining colon mucosa (arrows). (f) A cut section of large intestine in rats from $\mathrm{UC}+$ Olmesartan $10 \mathrm{mg} / \mathrm{kg} /$ day treated group showing intense immune reaction with mild immune-positive nuclei in the cells lining colon mucosa (arrows).

Effects of olmesartan on colonic tissue contents of lipid peroxidation (MDA) and reduced glutathione (GSH)

In ulcerative colitis non treated group and olmesartan (1 $\mathrm{mg} / \mathrm{kg} /$ day, orally) treated group showed significant elevation of lipid peroxidation (MDA) levels, while level of reduced glutathione showed marked reduction comparing with normal control group (Table 2). On the other hand, level of colonic tissue (MDA) was significantly reduced in olmesartan $(5 \mathrm{mg} / \mathrm{kg} /$ day, 10 $\mathrm{mg} / \mathrm{kg} /$ day) treated groups compared with ulcerative colitis non-treated group (Table 2). While, level of colonic 
tissue contents of reduced glutathione was significantly elevated in the same groups compared with ulcerative colitis non-treated group (Table 2).

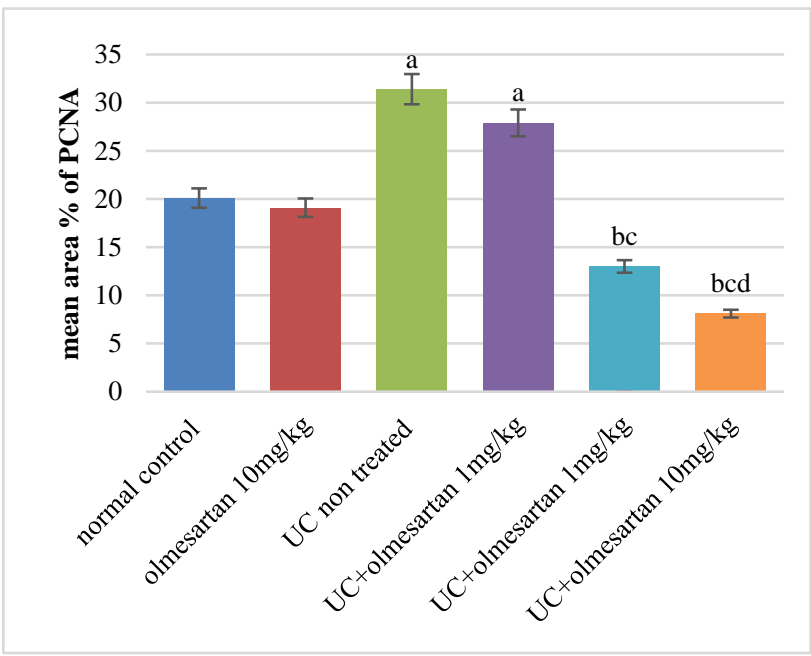

Figure 9: Histogram showing the mean area $\%$ of proliferative cell nuclear antigen $(\mathrm{PCNA}) \pm \mathrm{SD}$ in different studied groups.

$\mathrm{N}$ : B: (a) significant difference between UC non-treated group with normal control group, (b) significant difference between olmesartan treated groups and UC non treated group, (c) significant difference between UC + olmesartan $5 \mathrm{mg} / \mathrm{kg} /$ day treated group and olmesartan $1 \mathrm{mg} / \mathrm{kg} /$ day treated group and (d) significant difference between UC + olmesratn $10 \mathrm{mg} / \mathrm{kg} /$ day treated group and olmesartan $5 \mathrm{mg} / \mathrm{kg} /$ day treated group.

Table 1: The effects of olmesartan on colonic tissue levels of TNF- $\alpha$ and myeloperoxidase (MPO) in different studied groups.

\begin{tabular}{|lll|}
\hline Groups & $\begin{array}{l}\text { TNF- } \alpha \\
\text { (pg/g } \\
\text { tissue) }\end{array}$ & $\begin{array}{l}\text { Myeloperoxidase } \\
\text { (U/g tissue) }\end{array}$ \\
\hline Normal control & $55.2 \pm 3.3$ & $13.5 \pm 0.8$ \\
\hline $\begin{array}{l}\text { Olmesartan 10 } \\
\text { mg/kg treated }\end{array}$ & $53.1 \pm 2.9$ & $14.1 \pm 0.5$ \\
\hline $\begin{array}{l}\text { Ulcerative colitis } \\
\text { (UC) non- } \\
\text { treated }\end{array}$ & $150.4 \pm 2.4^{\mathrm{a}}$ & $70.3 \pm 3.2^{\mathrm{a}}$ \\
\hline $\begin{array}{l}\text { UC + } \\
\text { olmesartan 1 } \\
\text { mg/kg treated }\end{array}$ & $130.7 \pm 2.9^{\mathrm{a}}$ & $60.9 \pm 2.8^{\mathrm{a}}$ \\
\hline $\begin{array}{l}\text { UC + } \\
\text { olmesartan 5 } \\
\text { mg/kg treated }\end{array}$ & $84.2 \pm 3.1^{\mathrm{bc}}$ & $33.7 \pm 2.1^{\mathrm{bc}}$ \\
\hline $\begin{array}{l}\text { UC + } \\
\text { olmesartan 10 } \\
\text { mg/kg treated }\end{array}$ & $56.6 \pm 2.3^{\text {bcd }}$ & $17.2 \pm 1.1^{\mathrm{bcd}}$ \\
\hline
\end{tabular}

$\mathrm{N}$ : B: (a) significant difference between UC non-treated group with normal control group, (b) significant difference between olmesartan treated groups and UC non treated group, (c) significant difference between UC + olmesartan $5 \mathrm{mg} / \mathrm{kg} /$ day treated group and olmesartan $1 \mathrm{mg} / \mathrm{kg} /$ day treated group and (d) significant difference between UC + olmesratn $10 \mathrm{mg} / \mathrm{kg} / \mathrm{day}$ treated group and olmesartan $5 \mathrm{mg} / \mathrm{kg} /$ day treated group.
Table 2: Effects of olmesartan on colonic tissue levels of lipid peroxidation (MDA) and reduced glutathione (GSH) in different studied groups.

\begin{tabular}{|lll|}
\hline Groups & $\begin{array}{l}\text { (MDA) } \\
\text { (nmol/g } \\
\text { tissue) }\end{array}$ & $\begin{array}{l}\text { (GSH) }(\mathrm{nmol} / \mathrm{g} \\
\text { tissue) }\end{array}$ \\
\hline Normal control & $10.7 \pm 0.22$ & $1200.2 \pm 9.8$ \\
\hline $\begin{array}{l}\text { Olmesartan 10 } \\
\text { mg/kg/day } \\
\text { treated }\end{array}$ & $9.3 \pm 0.5$ & $1250.3 \pm 7.5$ \\
\hline UC non-treated & $76.7 \pm 4.3^{\mathrm{a}}$ & $500.8 \pm 5.2^{\mathrm{a}}$ \\
\hline $\begin{array}{l}\text { UC + } \\
\text { olmesartan 1 } \\
\text { mg/kg treated }\end{array}$ & $69.4 \pm 3.1^{\mathrm{a}}$ & $650.5 \pm 3.5^{\mathrm{a}}$ \\
\hline $\begin{array}{l}\text { UC + } \\
\text { olmesartan 5 } \\
\text { mg/kg treated }\end{array}$ & $41.1 \pm 3.5^{\mathrm{bc}}$ & $860.1 \pm 2.9^{\mathrm{bc}}$ \\
\hline $\begin{array}{l}\text { UC + } \\
\text { olmesartan 10 } \\
\text { mg/kg treated }\end{array}$ & $13.2 \pm 2.6^{\mathrm{bcd}}$ & $1150.3 \pm 1.8^{\mathrm{bcd}}$ \\
\hline
\end{tabular}

$\mathrm{N}$ : B: (a) significant difference between UC non-treated group with normal control group, (b) significant difference between olmesartan treated groups and UC non treated group, (c) significant difference between olmesartan $5 \mathrm{mg} / \mathrm{kg} /$ day treated group and olmesartan $1 \mathrm{mg} / \mathrm{kg} /$ day treated group and (d) significant difference between olmesratn $10 \mathrm{mg} / \mathrm{kg} /$ day treated group and olmesartan $5 \mathrm{mg} / \mathrm{kg} /$ day treated group.
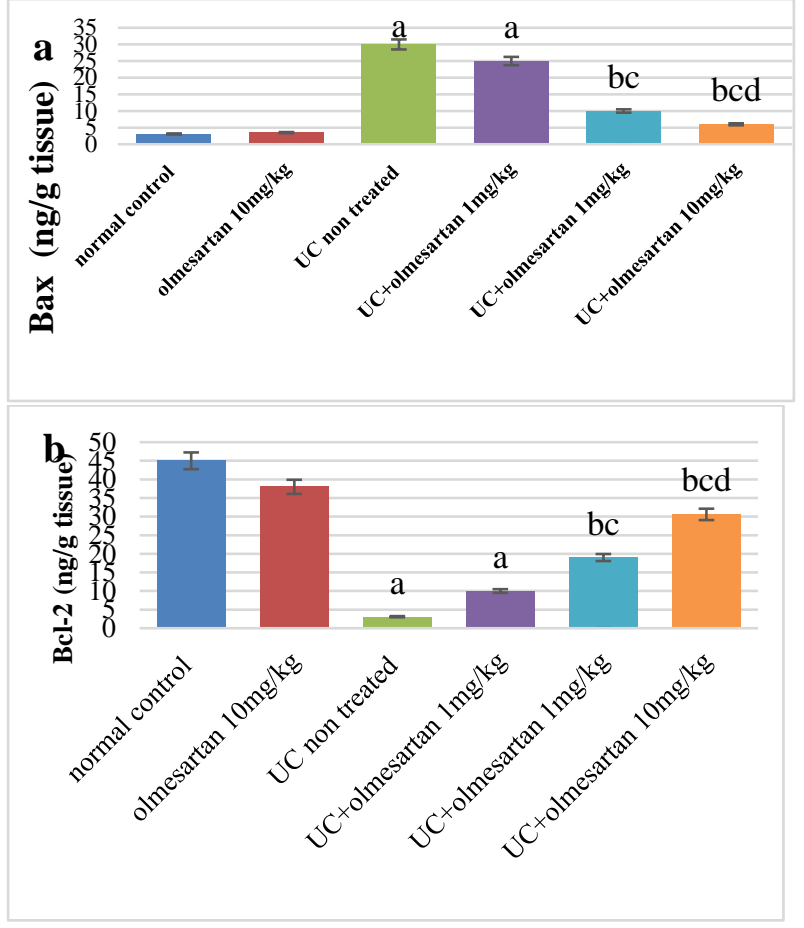

Figure 10 (a and b): Histogram showing the effects of olmesartan on Bax and Bcl-2 (ng/g tissue) \pm SD levels in different studied groups.

$\mathrm{N}$ : B: (a) significant difference between UC non-treated group with normal control group, (b) significant difference between olmesartan treated groups and UC non treated group, (c) significant difference between olmesartan $5 \mathrm{mg} / \mathrm{kg}$ treated group and olmesartan $1 \mathrm{mg} / \mathrm{kg} /$ day treated group and (d) significant difference between olmesratn $10 \mathrm{mg} / \mathrm{kg} /$ day treated group and olmesartan $5 \mathrm{mg} / \mathrm{kg} /$ day treated group. 


\section{Effect of olmesartan on apoptosis and antiapoptotic markers in rat colon}

In ulcerative colitis non treated group and UC-treated with olmesartan $(1 \mathrm{mg} / \mathrm{kg} / \mathrm{day}$, orally) there were significant increase in pro-apoptotic Bax level compared with normal control group (Figure 10). While, anti-apoptotic Bcl-2 protein was significantly reduced in the both groups. Treatment with olmesartan $(5 \mathrm{mg} / \mathrm{kg} / \mathrm{day}, 10 \mathrm{mg} / \mathrm{kg} /$ day $)$ significantly reversed the dextran sulfate stimulated raise of Bax/Bcl-2 ratio (Figure 10).

\section{DISCUSSION}

This study was designed to determine the potential ameliorative effect of olmesartan in treatment of UC in rats and its possible anti-proliferative, anti-apoptotic, antiinflammatory and antioxidant effects. These effects were measured based on severity of the disease activity index which included percentage of body weight loss, stool consistency, incidence of bloody diarrhea and confirmed by biochemical analysis, histological and immunohistochemistry examination of the colon tissue compared with the UC non-treated group.

Results of the present study determined that induction of ulcerative colitis by oral administration of dextran sulfate sodium (DSS) for 21 days in combination with intracolonic instillation of acetic acid for 3 consecutive days resulted in sever colitis manifested in rats by significant increase watery and bleeding diarrhea and loss of body weight. Biochemical results showed that significant increase in serum levels of TNF- $\alpha$ and interleukine-1B, colonic TNF- $\alpha$, myeloperoxidase (MPO), lipid peroxidation (MDA) levels and PCNA expression. While, level of interleukine-10 and reduced glutathione (GSH) were significantly decreased. All these data confirmed by histopathological and immunohistochemistry examination.

Our results are in consistence with Lei Zhu and his colleges, who found that DSS-induced UC in rats produced significant body weight loss, increase incidence of bloody stool and increase disease activity index in rats. Also, levels of IL-1, IL-6, TNF- $\alpha$, TGF-B, MPO and MDA were elevated. $^{12}$ Also, Wang and his team found that, in UC non treated rats there were increased levels of IL-1 $\beta$ and TNF- $\alpha$ and decreased levels of IL-10. ${ }^{18}$ Yang and his colleges demonstrated that, TNF- $\alpha$ is markedly increased in the colon of experimentally UC rats. ${ }^{19}$ The colon injuries become worse mainly by the release of IL-1 $\beta$ and TNF- $\alpha .^{13}$

On the other hand, treatment of olmesartan $(5 \mathrm{mg}, 10$ $\mathrm{mg} / \mathrm{kg} /$ day, orally) significantly ameliorate disease severity index of colitis by attenuating the production of IL-1 $\beta$, TNF- $\alpha$. In agreement with our results, Marchesi et al suggested that angiotensin II is a potent inflammatory mediator by stimulation of AT1 receptor, caused increased production of pro-inflammatory cytokines, inflammatory cell infiltration, lipid peroxidation and NF- $\kappa \mathrm{B}$ activation. ${ }^{20}$ Similar result was previously reported the antiinflammatory effect of olmesartan in many conditions as pulmonary fibrosis and vascular inflammation in patients with hypertension. ${ }^{21,22}$

In our work, the anti-inflammatory and anti-oxidative effects of Olmesartan were evaluated on the biochemical levels and confirmed by histological changes. The amplification of the neutrophil aggregation and infiltration measured by the content of myeloperoxidase in the colon. DSS/AA induced UC produced significant increase release of MPO and neutrophil infiltration in colon mucosa. This finding is in line with Sun et al, who suggested that neutrophil infiltration had a pivotal role in stimulating release of reactive oxygen species which then damage cell membrane and delayed ulcer healing in UC model in rats. ${ }^{8}$ So, attenuating of MPO activity and regulating tumor necrosis alpha and IL- $1 \beta$ can improve progression of UC. Treatment with olmesartan $(5 \mathrm{mg} / \mathrm{kg} / \mathrm{day}, 10 \mathrm{mg} / \mathrm{kg} /$ day $)$ significantly decreased neutrophil aggregation as measured by inhibition of colonic myeloperoxidase and confirmed by histopathological changes. Similar studies have shown similar results, Nagib et al, stated that angiotensin II increase neutrophil migration by increase release of chemokines by the combination of Ang II with AT1 receptor. ${ }^{23}$ In addition, Yamada et al., reported that candesartan and lisinopril improved inflammation and pancreatic fibrosis by reducing myeloperoxidase activity. ${ }^{24}$

Another point studied in our work revealed that induction of UC by DSS and AA increased oxidative stress marker (MDA) level and depletion of reduced glutathione (GSH). The results of current study go hand in hand with previous studies by Hartmann and Nagib et al, olmesartan ( $5 \mathrm{mg}, 10$ $\mathrm{mg} / \mathrm{kg} /$ day, orally) showed a remarkable decrease in lipid peroxidation and significant increase antioxidant level of GSH. These antioxidant effects of Olmesartan attenuate oxidative injury and progress healing in colon. ${ }^{3,23}$ This finding is in consistence with previous work which revealed that olmesartan has a potent antioxidant effect. ${ }^{23}$ Saber et al, found that olmesartan in a dose related dependent manner decreased signs of oxidative stress such as MDA and GSH levels. ${ }^{25}$ Many studies are in line with our data, it was documented that olmesartan had therapeutic effect in many pathological conditions due to its antioxidant effects. Another study by Takahashi and his colleges, reported that treatment with different doses of Olmesartan decreased lipid peroxidation as measured by significant reduction of MDA and preserve GSH in rats with model of renal injury. ${ }^{26}$ Fujimoto et al stated that angiotensin II increase release of oxygen free radical and superoxide production and olmesartan was significantly decrease release of reactive oxygen species in isolated normal glomeruli. ${ }^{27}$ Also, olmesartan decreased interleukins release and oxidative stress markers in patients with heart failure. ${ }^{28}$ Another ARBs as valsartan had ameliorated oxidative stress in acute pancreatitis and 
azilsartan relieved oral mucositis induced by 5fluorouracil. ${ }^{9,} 29$

The risk of dysplasia and colorectal cancer is significantly increased in people with ulcerative colitis after ten years. Impairment of cell proliferation is likely responsible for dysplasia and colorectal carcinoma. ${ }^{30}$ This point was measured in our work by measuring pro-apoptotic Bax and anti-apoptotic Bcl-2 protein levels and immunohistochemistry demonstration of PCNA. In the current study, UC non-treated group showed marked increase in the level of apoptotic Bax compared with antiapoptotic Bcl-2 protein and increase expression of PCNA immunopositivity nucleai in mucosal crypts. These results are in agreement with Andaloussi et al, who stated that, apoptosis level was increased by intestinal inflammation. ${ }^{30}$ Also, Shinozaki et al, demonstrated that UC is accompanied by high proliferating activity in intestinal mucosa with increased risk of colorectal neoplasia in rats, and in patients with UC. ${ }^{17}$ In our study Olmesartan $(5 \mathrm{mg}$, $10 \mathrm{mg} / \mathrm{kg} /$ day) produced significant reduction of the ratio of apoptotic to anti-apoptotic protein markers Bax/Bcl-2 and PCNA as detected by immunolabeling. ${ }^{31}$ These results are in line with Saber et al., who reported that olmesartan ameliorated $\mathrm{UC}$ in rats by restoring the normal ratio between Bax/Bcl-2 apoptotic proteins. ${ }^{25}$ Xuan et al, found that olmesartan have anti-proliferative effect on tendon capsule fibroblasts. ${ }^{32}$ And Aizawa et al, who stated that Ang II potentiated the development of renal cell proliferation and apoptosis in hypertensive diseased patients. $^{33}$

\section{CONCLUSION}

In conclusion, our results pointed out that olmesartan had potential therapeutic effect in UC induced experimentally in rats at the doses of $(5 \mathrm{mg} / \mathrm{kg} / \mathrm{day}, 10 \mathrm{mg} / \mathrm{kg} / \mathrm{day})$. Olmesartan improved disease activity index, significantly decreased colonic tissue levels of TNF- $\alpha$, myeloperoxidase (MPO) and malondiadehyde (MDA). Significantly decrease serum IL- $1 \beta$ and TNF- $\alpha$. while, serum anti-inflammatory IL-10 was increased. Olmesartan restored the normal ratio of pro-apoptotic Bax to antiapoptotic Bcl-2 protein and finally down regulation of proliferative cell nuclear antigen. All these results confirmed by histological and immunohistochemistry examination. Therefore, olmesartan beneficial effects are possibly related to its anti-inflammatory, anti-oxidant, antiapoptotic effects and modulating cell proliferation. This study suggests that olmesartan may be promising drug in the treatment of ulcerative colitis and preventing apoptosis and colorectal cancer associated with the disease.

\section{ACKNOWLEDGEMENTS}

Deep gratitude and appreciation to Faculty of Medicine, Benha University for great help and valuable constructive cooperation in this work.
Funding: No funding sources

Conflict of interest: None declared

Ethical approval: The study was approved by the Institutional Ethics Committee

\section{REFERENCES}

1. Zeng Z, Zhu Z, Yang Y, Ruan W, Peng X. Incidence and clinical characteristics of inflammatory bowel disease in a developed region of Guangdong Province, China: a prospective population-based study. J Gastroenterol Hepatol. 2013;28(7):1148-53.

2. Wirtz S, Neufert C, Weigmann B, Neurath MF. Chemically induced mouse models of intestinal inflammation. Nat Protoc. 2007;2(3):541-6.

3. Hartmann RM, Martins MI, Tieppo J, Fillmann HS, Marroni NP. Effect of Boswellia serrata on antioxidant status in an experimental model of colitis rats induced by acetic acid. Dig Dis Sci. 2012;57(8):2038-44.

4. Boussenna A, Cholet J, Goncalves-Mendes N, Joubert-Zakeyh J, Fraisse D. Polyphenol-rich grape pomace extracts protect against dextran sulfate sodium-induced colitis in rats. J Sci Food Agric. 2016; 96(4):1260-8.

5. Hozumi H, Hokari R, Kurihara C, Narimatsu K, Sato $\mathrm{H}$, Sato $\mathrm{S}$, et al. Endoscopic finding of spontaneous hemorrhage correlates with tumor necrosis factor alpha expression in colonic mucosa of patients with ulcerative colitis. Int $\mathrm{J}$ Colorectal Dis. 2013;28(8):1049-55.

6. Matuszyk A, Ceranowicz P, Warzecha Z, Cieszkowski J, Ceranowicz D, Gałązka K, et al. Exogenous Ghrelin Accelerates the Healing of Acetic Acid-Induced Colitis in Rats. Int J Mol Sci. 2016;17(9):1455.

7. Guerra GCB, Menezes MSSD, Araújo AAD, Júnior RFDA, Medeiros CACXD. Olmesartan Prevented Intra-articular Inflammation Induced by Zymosan in Rats. Biol Pharm Bull. 2016;39(11):1793-801.

8. Sun AN, Ren GY, Deng C, Zhang JJ, Luo XP, Wu XJ, et al. C-glycosyl flavonoid orientin improves chemically induced inflammatory bowel disease in mice. J Funct Foods. 2016;21:418-30.

9. Araújo AAD, Varela H, Brito GADC, Medeiros CACXD, Araújo LDS, Nascimento JHOD, et al. Azilsartan increases levels of IL-10, down-regulate MMP-2, MMP-9, RANKL/RANK, Cathepsin K and up-regulates $\mathrm{OPG}$ in an experimental periodontitis model. PLoS One. 2014;9:6750.

10. David E Mire 1, Tonous N Silfani, Michael K Pugsley. A review of the structural and functional features of olmesartan medoxomil, an angiotensin receptor blocker. J Cardiovasc Pharmacol 2005 Nov; 46(5):585-93.

11. Aurigena Antunes Araújo 1, Graziene Lopes de Souza, Tatiana Oliveira Souza, Gerly Anne de Castro Brito, Karoline Sabóia Aragão, Caroline Addison Xavier de Medeiros, Yriu Lourenço, Maria do Socorro Costa Feitosa Alves, Raimundo Fernandes de Araújo Jr. Olmesartan decreases IL-1 $\beta$ and TNF- $\alpha$ levels; downregulates MMP-2, MMP-9, COX-2, and 
RANKL; and upregulates OPG in experimental periodontitis. Naunyn Schmiedebergs Arch Pharmacol. 2013 Oct; 386(10):875-84.

12. Lei Zhu, PeiQing GU, Hong Shen. Protective Effects of Berberine Hydrochloride on DSS-induced Ulcerative Colitis in Rats. Int immunopharmacology. 2019;68:242-251.

13. Puneet Kaur Randhawa 1, Kavinder Singh 1, Nirmal Singh 1, Amteshwar Singh Jaggi 1. A review on chemical-induced inflammatory bowel disease models in rodents. Korean $\mathbf{J}$ Physiol Pharmacol 2014;18(4):279-88.

14. R.F. de Araújo Júnior, M.P.O. da Silva Reinaldo, G.A. de Castro Brito, P. de França Cavalcanti, M.A. de Moura Freire, C.A.X. de Medeiros, A.A. de Araújo. Olmesartan decreased levels of IL- $1 \beta$ and TNF- $\alpha$, down-regulated MMP-2, MMP-9, COX-2, RANK/RANKL and up-regulated SOCs-1 in an intestinal mucositis model. PLoS One, 2014: e114923.

15. Weaker FJ, Richardson L: A modified processing and sectioning technique for hard tissues. Am J Med Technol. 1978;44(10):1030-2.

16. Noori, S.; Nasir, K and Mahboob, T. Effect of cocoa powder on oxidant /antioxidant in liver, heart and kidney tissue of rats The $\mathbf{J}$ Animal Plant Sci. 2020;4:174-8.

17. Noffsinger AE, Belli JM, Fogt F, Fischer J, Goldman $\mathrm{H}$, Fenoglio-Preiser CM.A. germline hMSH2 alteration is unrelated to colonic microsatellite instability in patients with ulcerative colitis. Hum Pathol. 1999;30(1):8-12.

18. Wang YN, Li J, Zheng WY, Wu D, Yang H, Li Y, Lv H, Tan B, Shu HJ, Sun XY, Qian JM, Wu B, Li JN. Clinical characteristics of ulcerative colitis-related colorectal cancer in Chinese patients. J Dig Dis. 2017; 18(12):684-690.

19. Yang M, Lin HB, Gong S, Chen PY, Geng LL, Zeng YM, Li DY..Effect of Astragalus polysaccharides on expression of TNF- $\alpha$, IL-1 $\beta$ and NFATc4 in a rat model of experimental colitis. Cytokine. 2014 Dec; 70(2):81-6.

20. Marchesi C, Paradis P, Schiffrin EL. Role of the reninangiotensinsystem in vascular inflammation. Trends Pharmacol Sci. 2008;29(7):367-374.

21. Y. Waseda, M. Yasui, Y. Nishizawa, K. Inuzuka, H. Takato, Y. Ichikawa, A. Tagami, M. Fujimura, S. Nakao: Angiotensin II type 2 receptor antagonist reduces bleomycin-induced pulmonary fibrosis in mice. Resp. Res. 2008;9:43.

22. S. David, P. Kümpers, A. Lukasz, J.T. Kielstein, H. Haller, D. Fliser: Circulating angiopoietin-2 in essential hypertension: relation to atherosclerosis, vascular inflammation, and treatment with olmesartan/pravastatin. J. Hypertens. 2009;27:16411647.

23. M.M. Nagib, M.G. Tadros, M.I. ELSayed, A.E. Khalifa. Anti-inflammatory and anti-oxidant activities of olmesartan medoxomil ameliorate experimental colitis in rats. Toxicol. Appl. Pharmacol., 271 (2013), pp. 106-113

24. T. Yamada, A. Kuno, K. Ogawa, M. Tang, K. Masuda, S. Nakamura, T. Ando, T. Okamoto, H. Ohara, T. Nomura. Combination therapy with an angiotensinconverting enzyme inhibitor and an angiotensin II receptor blocker synergistically suppresses chronic pancreatitis in rats. J. Pharmacol. Exp. Ther., 313 (2005), pp. 36-45

25. Saber S, Khalil RM, Abdo WS, Nassif D, El-Ahwany E. Olmesartan ameliorates chemically-induced ulcerative colitis in rats via modulating NFKB and Nrf2/HO-1 signaling crosstalk Toxicol Appl Pharmacol. 2019 Feb 1; 364:120-132.

26. Sohachi Fujimoto 1, Minoru Satoh, Hideyuki Horike, Hidekazu Hatta, Yoshisuke Haruna, Shinya Kobayashi, Tamehachi Namikoshi, Sayaka Arakawa, Naruya Tomita, Naoki Kashihara Olmesartan ameliorates progressive glomerular injury in subtotal nephrectomized rats through suppression of superoxide production. Hypertens Res 2008; 31(2):305-13.

27. Takahashi T, Konta T, Takasaki S, Ichikawa K, Takeishi Y, Kubota I. An angiotensin II type-I receptor blocker, olmesartan medoxomil, attenuates lipid peroxidation in renal injury induced by subtotal nephrectomy. Clin Exp Nephrol. 2007;11(3):202-8.

28. M. Tsuda, M. Iwai, J.-M. Li, H.-S. Li, L.-J. Min, A. Ide, M. Okumura, J. Suzuki, M. Mogi, H. Suzuki. Inhibitory effects of AT1 receptor blocker, olmesartan, and estrogen on atherosclerosis via antioxidative stress. Hypertension. 2005;45:545-51.

29. Zhijian Pan 1, Ling Feng 2, Haocheng Long 3, Hui Wang 1, Jiarui Feng 3, Feixiang Chen Effects of Local Pancreatic Renin-Angiotensin System on the Microcirculation of Rat with Severe Acute Pancreatitis. Korean J Physiol Pharmacol. 2015;19(4):299-30.

30. S.E. Andaloussi, I. Mäger, X.O. Breakefield, and M.J. Wood: Extracellular vesicles: biology and emerging therapeutic opportunities. Nat. Rev. Drug Discov., 12 (2013), p. 347 View Record in Scopus.

31. M Shinozaki 1, T Watanabe, Y Kubota, T Sawada, H Nagawa, T Muto. High proliferative activity is associated with dysplasia in ulcerative colitis. Dis Colon Rectum. 2000;43(10 Suppl): S34-9.

32. Xuan Wang, Ya-Zhi Fan, Liang Yao, Jian-Ming Wang.: Anti-proliferative effect of olmesartan on Tenon's capsule fibroblasts. Int J Ophthalmo 2016; 9(5):669-76.

33. T Aizawa, N Ishizaka, K Kurokawa, R Nagai, H Nakajima, J Taguchi, M Ohno. Different effects of angiotensin II and catecholamine on renal cell apoptosis and proliferation in rats Kidney Int 2001;59(2):645-53.

Cite this article as: Emam HT, Hussien NI, Ibrahim AN. Olmesartan modulates proliferating cell nuclear antigen expression and improves dextran sulfate induced ulcerative colitis in rats. Int J Basic Clin Pharmacol 2021;10:209-19. 